\title{
韓国の木造文化財建造物における合成樹脂を用いた部材の修復について A STUDY OF MEMBERS REPAIR USING SYNTHETIC RESINS OF HISTORIC WOODEN ARCHITECTURE IN KOREA
}

\author{
趙 賢 貞* \\ Hyunjung $\mathrm{CHO}$
}

\begin{abstract}
The aim of this paper is to identify repair of architectural members in Korean heritage, consider their historic development, and analyze repair and restoration cases. Data used for analysis are mainly reports and specification documents of heritage buildings' repair and restoration works, complemented by field surveys on repair work sites.

This study clarifies issues of traditional repair in Korean architectural heritage and analyzes the introduction of synthetic resins in repair as follows: the process of introduction of synthetic resins from Japan in 1978; the development of their use in conservation and repair work sites since then; and analysis of synthetic resins used for repairs, execution techniques and architectural members to which these application were applied.
\end{abstract}

Analysis results show that the application of synthetic resins in architectural repair in mostly limited to large section members and certain parts of members. Analysis results point out the issues and problems of repairs.

Keywords: Wooden Architecture, Synthetic Resin, Repair of members, Cultural Heritage, Republic of Korea 木造建造物，合成樹脂，部材修復，文化財，韓国

\section{1.はじめに}

木造文化財建造物における部材の修復は、腐朽・虫害・漏水・災 害などで破損・焼損した部材を、本来の役割が果たせるよう適切な 処置を施すことである。そのなかに人工木材・合成樹脂処理などと 称される合成樹脂を用いた部材の修復がある。

韓国の木造文化財建造物において、合成樹脂を用いた部材の修復 に関する研究は大きく二系統に分類でき、一つは文化財建造物の施 工に応用寸る実験・報告に関する研究 ${ }^{1)}$ 、もう一つは施工に関する 事例研究である ${ }^{2)}$ 。合成樹脂の使用は約 30 年が経過しており、これ までの過程や用法およびその特徵等を把握し、今後の文化財建造物 の保存に反映させる時期に来ていると思われる。そこで本研究は、 韓国における木造建造物の合成樹脂を用いた部材修復を対象 (詳細 項目は表 1)とし ${ }^{3)}$ 、使用事例の詳細な分析・検討をもとに、今後の 木造文化財建造物の修理における合成樹脂の適用の方向性を考察寸 ることを目的とする。

本研究の構成は、まず韓国の建造物修理における伝統的な技法と 合成樹脂の導入に至った経緯を分析する。つぎに 1978 年以降の文化 財建造物の修理工事をもとに、合成樹脂を用いた部材の修復の展開 と、適用された部材や施工技法、文化財修理に適用された合成樹脂 の材質的な特性を検討する。これらより、韓国の文化財建造物修理 における合成樹脂の問題点と今後の課題について論じる。

本研究における資料は、おもに文化財修理報告書や文化財修理標 準仕様書とするが、併せて修理工事の実地調查も加えた。

\section{2. 部材の修復における伝統的な技法と合成樹脂の導入}

韓国における伝統的な部材の修復は、(1)柱の根元を繕う根継、(2) 木や釷を用いて繕う知木、(3)金物による補強に大別できる。

根継は、「ドンバリ」と称され、朝鮮時代の王室あるいは国の主要 行事の内容を整理した記録『儀軌』では、「童發里」、「童發伊」、「東 發里」、「同發耳」と表記しており ${ }^{4)}$ 、根継の技法は少なくとも朝鮮 時代から施されていたことがわかる ${ }^{5)}$ 。現在の修理工事でも、根継 は宮殿・寺院・民家など種類を問わず、広く用いられている(図 1、 図 2)。『文化財修理標準仕様書』にも根継による施工内容を載せて、 この技法を継承するようにしている。

知木については相当するものが『儀軌』に確認できない。最近の ソウル崇礼門 (南大門)の修理事例があり ${ }^{6)}$ 、破損した 1 階地隅木外 側 (図 3 の丸印) 、桁、台輪など、鴙木して釘で固定していることが 確認できる。この処置は 1962 年の修理、或は、それ以前の修理と考 えられ、合成樹脂の導入以前の修復技法のひとつといえる。

金物による補強については、ソウル崇礼門 (1962 年修理)の記録 7) や鳳停寺極楽殿 (1972-1973 年修理)の記録 ${ }^{8)}$ にみられる。崇礼門の 場合は、隅木の荷重を直接に受けた丸桁を支える隅肘木や台輪など を金物で補強された。隅肘木の破損は、丸桁が直角に交差する支点 に荷重が集中したことが原因であり、図4 のように帯鉄で補強され た。台輪は継手部分を帯鉄で補強された。鳳停寺極楽殿では、破損 した梁の頭部を帯鉄で補強された。金物を用いた部材の補強は朝鮮 時代の新築や移築にも用いられたが、このように補強に用いられた 時期は明らかでない。

\footnotetext{
$*$ 東京藝術大学大学院美術研究科 博士後期課程 $($ 保存 $) \cdot$ 工修
} 
このような根継、矧木、金物による部材の修復は、合成樹脂が導 入される以前の伝統的技法に属するものである。1960 年代から 1970 年代にかけて、現在の文化財に関する概念形成を巡る動向があり ${ }^{9}$ 、 それに伴って、文化財建造物の保存技術における当面の課題につい て検討されるようになった ${ }^{10)}$ 。そこで、合成樹脂による部材の修復 に関心が持たれるようになったが ${ }^{11}$ 、この段階では合成樹脂に関す る具体的な用法や技術が充分に把握されておらず、その後、日本に おける施工技術を導入することになった。

1978 年、建造物の修理工事において、初めて合成樹脂を用いて部
材が修復された ${ }^{12)}$ 。当時、松広寺枕溪楼や採薇亭における部材の処 置を韓国国立文化財研究所 (NRICH)の金柄虎氏が担当した。金氏は 当時の考え方を「エポキシ樹脂は、通気性が殆どなく、温度変化に よくない短所はあるが、接着性・耐水性・耐久性が優秀で、耐腐敗 性の材料で、比較的いい材料として認識される。」と述べている ${ }^{13)}$ 。

これより、合成樹脂は当時のある程度の検証された材料として認識 されたことが知られる。これ以後、文化財建造物の保存修理には、 合成樹脂を用いて部材を修復するようになったが、それらを修理年 次順で整理したのが表 1 である。

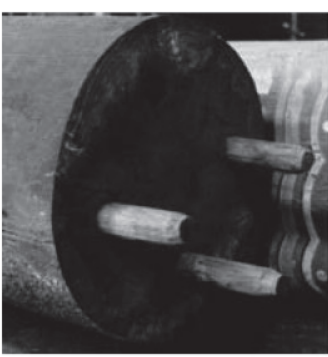

図 1 ソウル徳壽宮大漢門 (柱根継部分)

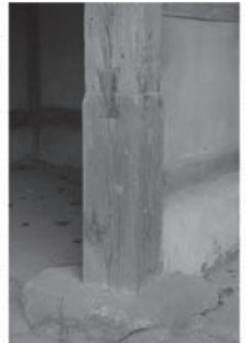

図 2 洪城㛜嗓古宅 (柱根継部分)

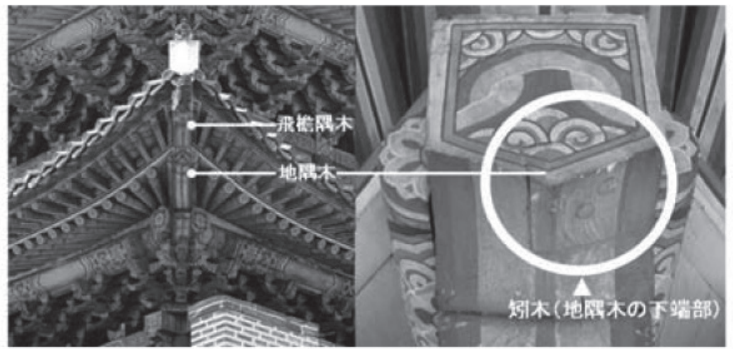

図 3 崇礼門の 1 階地隅木(知木で補修)

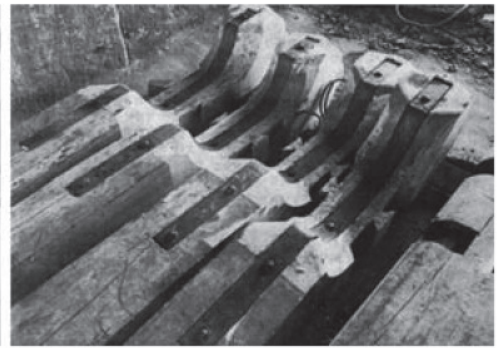

図 4 崇礼門の隅肘木(帯鉄で修理)

表 1 合成樹脂を用いた部材の修復に関する建造物一覧

\begin{tabular}{|c|c|c|c|c|c|c|c|c|c|c|c|}
\hline $\begin{array}{l}\text { 番 } \\
\text { 号 }\end{array}$ & 修理期間 & 建物名 & 指定 & 建立年代 & 所在地 & 析行X梁間 & 屋根 & $\begin{array}{l}\text { 階 } \\
\text { 数 }\end{array}$ & $\begin{array}{l}\text { 彩 } \\
\text { 色 }\end{array}$ & 天井 & 合成樹脂で修復した部材 \\
\hline 1 & 1978 & 松広寺枕溪楼 & 非指定 & 1688 & 全南 & $7 \times 3$ & 切妻 & 2 & 0 & 格 & 柱、初重梁、二重梁、三重梁、标、組物材、大引 ${ }^{14)}$ \\
\hline 2 & 1978 & 亀尾採薇亭 & 市道 55 & 1768 & 慶北 & $3 \times 2$ & 入母 & 1 & $\mathrm{x}$ & 化粧 & 柱 \\
\hline 3 & 1979 & 禅雲寺萬歳楼 & 市道 53 & 1613 & 全南 & $9 \times 2$ & 切妻 & 1 & $\mathrm{O}$ & 化粧 & 初重梁 \\
\hline 4 & 1981 & 尚州養䢐堂 & 市道 85 & 1626 & 慶北 & $6 \times 9 \times 4$ & 切妻 & 1 & $\mathrm{x}$ & 複合 & 柱、地貫 \\
\hline 5 & 1981 & 崇陵 (東九陵)丁字閣 & 史跡 193 & 1800 年代 & 京畿 & $5 \times 5$ & 入母 & 1 & $\mathrm{O}$ & 化粧 & 初重梁 \\
\hline 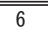 & $1981-1982$ & 花嚴寺雨花楼 & 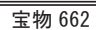 & 1711 以前 & 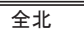 & $3 \times 2$ & 切妻 & 2 & 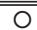 & 化粧 & 柱 \\
\hline 7 & \begin{tabular}{|l|}
$1981-1983$ \\
\end{tabular} & 無量寺極楽殿 & 宝物 356 & 1700 年代 & 忠南 & $5 \times 4$ & 入母 & 2 & $\mathrm{O}$ & 格 & 初重梁 \\
\hline 8 & 1982 & 麗水鎭南館 & 宝物 324 & 1598 & 全南 & $15 \times 5$ & 入母 & 1 & 0 & 化粧 & 柱 \\
\hline 9 & 1982 & 金山寺弥勒殿 & 宝物 62 & 1635 & 全北 & $5 \times 4$ & 入母 & 3 & 0 & 格 & 柱 \\
\hline 10 & \begin{tabular}{|l|}
$1982-1983$ \\
\end{tabular} & 海印寺藏經板殿 (西寺刊庫) & 国宝 52 & 1457 & 慶南 & $2 \times 1$ & 切妻 & 1 & $\mathrm{x}$ & 化粧 & 柱 \\
\hline 11 & 1983 & 興仁之之門（東大門） & 宝物 1 & 1869 & ソウル & $5 \times 2$ & 寄棟 & 2 & $\mathrm{o}$ & 化粧 & 柱 \\
\hline 12 & 1983 & 松広寺下舍堂 & 宝物 263 & 1622 & 全南 & $3 \times 2$ & 切妻 & 1 & $\mathrm{x}$ & 複合 & 柱 \\
\hline 13 & 1983 & 扶蘇山城迎日楼 & 市道 101 & 1871 & 忠南 & $3 \times 2$ & 入母 & 2 & 0 & 化粧 & 柱 \\
\hline 14 & 1986 & 禅雲寺萬歳楼 (第 2 次) & 市道 53 & 1613 & 全南 & $9 \times 2$ & 切妻 & 1 & $\mathrm{O}$ & 化粧 & 柱 \\
\hline 15 & 1986 & 昌德宮敦化門 & 宝物 383 & 1608 & ソウル & $5 \times 2$ & 寄棟 & 2 & 0 & 化精 & 柱、初重梁 \\
\hline 16 & 1986 & 昌慶宮弘化門 & 宝物 384 & 1616 & ソウル & $3 \times 2$ & 寄棟 & 2 & $\mathrm{O}$ & 化粧 & 柱 \\
\hline 17 & 1986 & 昌慶宮明政門および回廊 & 宝物 385 & 1616 & ソウル & $3 \times 2$ & 入母 & 1 & 0 & 複合 & 柱 \\
\hline 18 & \begin{tabular}{|l|}
$1986-1987$ \\
\end{tabular} & 威鳳寺普光明殿 & 宝物 608 & 1600 年代 & 全北 & $3 \times 3$ & 入母 & 1 & $\mathrm{O}$ & 格 & 初重梁 \\
\hline 19 & \begin{tabular}{|l|l|}
1987 \\
\end{tabular} & 雙溪寺大雄殿 & 宝物 500 & 1632 & 慶南 & $5 \times 3$ & 入母 & 1 & 0 & 格 & 柱 \\
\hline 20 & 1987 & 宗廟正殿 & 宝物 227 & 1608 & ソウル & $19 \times 3$ & 切妻 & 1 & $\mathrm{O}$ & 格 & 柱 \\
\hline 21 & 1990 & 全州客舍 & 宝物 583 & 1400 年代 & 全北 & $5 \times 3,3 \times 3,3 \times 3$ & 切 $+\lambda$ & 1 & $\mathrm{O}$ & 化粧 & 柱、初重梁 \\
\hline 22 & 1990 & 景福宮勤政門および行閣 & 宝物 812 & 1867 & ソウル & $3 \times 2$ & 寄棟 & 2 & 0 & 複合 & 柱 \\
\hline 23 & 1991 & 晋州城钼南布政司門楼 & 市道 3 & 1618 & 慶南 & $3 \times 2$ & 入母 & 2 & $\mathrm{O}$ & 複合 & 柱 \\
\hline 24 & 1991-1999 & 金山寺弥勒殿 & 宝物 62 & 1635 & 全北 & $5 \times 4$ & 入母 & 3 & 0 & 格 & 柱、初重梁、二重梁、析、大斗、大引、隅木、飛浐隅木 \\
\hline 25 & $2000-2003$ & 景福宮勤政門 & 宝物 812 & 1867 & ソウル & $3 \times 2$ & 寄棟 & 2 & $\mathrm{O}$ & 複合 & 飛檐隅木、隅木、頭貫、束柱、建具 \\
\hline 26 & 2000-2003 & 景福宮勤政殿 & 国宝 223 & 1867 & ソウル & $5 \times 5$ & 入母 & 2 & $\mathrm{O}$ & 格 & 頭貫、按草工 ${ }^{15)}$ 、隅木、飛檐隅木、組物材 \\
\hline 27 & 2000-2004 & 花嚴寺極楽殿 & 宝物 663 & 1605 & 全北 & $3 \times 3$ & 切妻 & 1 & 0 & 格 & 柱、頭貫、初重梁、二重梁、㮏、組物材、飛售垂木 \\
\hline 28 & $2000-2004$ & 江陵客舎門 & 国宝 51 & 高麗末 & 江原 & $3 \times 2$ & 切妻 & 1 & $\mathrm{x}$ & 化粧 & 柱、初重梁、桁、大斗、組物材 \\
\hline 29 & 2001 & 永川鄉校大成殿 & 宝物 616 & 1513 & 慶南 & $5 \times 3$ & 入母 & 2 & 0 & 化粧 & 初重梁、頭貫、桁、建具 \\
\hline 30 & 2001 & 德壽宮中和殿 & 宝物 819 & 1906 & ソウル & $5 \times 4$ & 入母 & 1 & O & 格 & 飛檐隅木 \\
\hline 31 & $2001-2002$ & 崇林寺普光殿 & 宝物 825 & 1600 以前 & 全北 & $3 \times 3$ & 切妻 & 1 & 0 & 格 & 柱、初重梁、組物材 \\
\hline 32 & 2001-2002 & 清平寺回転門 & 宝物 164 & 1550 年代 & 江原 & $3 \times 1$ & 切妻 & 1 & 0 & 化粧 & 梁 \\
\hline 33 & 2001-2003 & 鳳停寺極楽殿 & 国宝 15 & 1200 年代 & 慶北 & $3 \times 4$ & 切妻 & 1 & 0 & 化粧 & 初重梁、二重梁、三重梁、組物材、析、頭貫、地貫、双首笔 16) \\
\hline 34 & $2001-2005$ & 法住寺大雄殿 & 宝物 915 & 1624 & 忠北 & $7 \times 4$ & 入母 & 2 & 0 & 格 & 柱、台輪 \\
\hline 35 & 2002-2004 & 佛甲寺大雄殿 & 宝物 830 & 1700 頃 & 全南 & $3 \times 3$ & 入母 & 1 & 0 & 格 & 柱、台輪、化粧垂木、二重梁、大引、隅木、飛售隅木 \\
\hline 36 & $2002-2004$ & 全州客舎 & 宝物 583 & 1471 以前 & 全北 & $4 \times 2,4 \times 2$ & 切 $+\lambda$ & 1 & 0 & 化粧 & 初重梁、二重梁 \\
\hline 37 & 2003 & 昌德宮上凉亭 & 史跡 122 & 1900 頃 & ソウル & 六角平面 & 六角 & 1 & 0 & 格 & 隅木 \\
\hline 38 & 2003 & 昌德宮熙政堂 & 宝物 815 & 1920 以前 & ソウル & $11 \times 4$ & 入母 & 1 & $\mathrm{O}$ & 格 & 柱 \\
\hline 39 & 2003-2004 & 梵魚寺大雄殿 & 宝物 434 & 1613 & 釜山 & $3 \times 3$ & 切妻 & 1 & O & 格 & 初重梁、建具 \\
\hline 40 & 2003-2004 & 浄水寺法堂 & 宝物 161 & 1423 & 京畿 & $3 \times 4$ & 切妻 & 1 & $\mathrm{O}$ & 格 & 柱、梁 \\
\hline 41 & 2003-2005 & 歸信寺大寂光殿 & 宝物 826 & 1600 年代 & 全北 & $5 \times 3$ & 切妻 & 1 & 0 & 格 & 柱、初重梁、頭貫、桁、組物材、化粧垂木 \\
\hline 42 & 2003-2005 & 桐華寺大雄殿 & 宝物 1563 & 1732 & 慶南 & $3 \times 3$ & 入母 & 1 & O & 格 & 柱、台輪、頭貫 \\
\hline 43 & 2003-2007 & 石南寺霊山殿 & 宝物 823 & 1600 年代 & 京畿 & $3 \times 2$ & 入母 & 1 & 0 & 格 & 柱、組物材 \\
\hline 44 & 2004 & 仁川都護府廳舍 & 市道 1 & 1677 & 仁川 & $3 \times 2$ & 切妻 & 1 & 0 & 化粧 & 柱 \\
\hline 45 & 2004-2005 & 德壽宮大漢門 & 史跡 124 & 1904 & ソウル & $3 \times 2$ & 寄棟 & 1 & $\mathrm{O}$ & 化粧 & 隅木、飛讐隅木、初重梁、二重梁 \\
\hline 46 & \begin{tabular}{|l|}
$2004-2007$ \\
\end{tabular} & 雙磎寺大雄殿 & 宝物 500 & 1632 & 慶南 & $5 \times 3$ & 入母 & 1 & 0 & 格 & 頭貫 \\
\hline
\end{tabular}


1978 年から 1981 年までは、松広寺枕溪楼、採薇亭、禅雲寺萬歳 楼、尚州養眞堂、崇陵 (東九陵)丁字閣の 5 件の工事があった。この うち松広寺枕溪楼は文化財ではなく、次の採薇亭は市指定建造物で ある。優劣で区別されたわけではないが、これらは本格的に国家指 定文化財へ導入する前の試験的な施工と推察される。

1981 年から 1991 年までは国家指定文化財に適用されたが、表 1 の部材の項目をみると処置された部材が少なく、柱や梁など一部の 部材に限られていることがわかる。合成樹脂による施工後、経年経 過の結果が出るまでは、少なくとも 10 年程度が必要であったことを 勘案すると、経年変化の結果を蓄積していた時期と考えられる。

1991 年以降はそれまでより件数が増加しただけでなく、合成樹脂 で修復された部材の種類が増えている。注目されるのが金山寺弥勒 殿の修理 (1991-1999) で、工事報告書から当時の保存科学技術を最大 限導入する方針や合成樹脂による部材の修復を奨励したことがわか っている ${ }^{17)}$ 。金山寺弥勒殿は韓国唯一に残る内部が通層で雄大荘厳 な 3 階建で、図 5 は金山寺弥勒殿の工事報告書より、合成樹脂で修 復した部材を図示したものである。太線で四角に囲った箇所がそれ に該当するところで、これより局所的でなく全体的に合成樹脂が適 用されたことが具体的に知られる。また下部直径最大 $600-750 \mathrm{~mm}$ 内 陣柱のであるなど、構成部材のほとんどが大径材であり、部材径が 大きいほど合成樹脂による修復が積極的に適用されたと思われる。

このように、1978 年より導入された合成樹脂による部材の修復に ついて、文化財建造物における適用の対象や範囲及び修理内容を分 析すると、韓国においては必ずしも順調に進展してきたのではなく、 段階的に展開していった様子がうかがえる。今日では合成樹脂によ る部材の修復が普遍的に行われているが、つぎに合成樹脂が適用さ れた修理部位や技法および施工の実態について考察する。

\section{3. 合成樹脂の使用部位と施工技法}

まず、合成樹脂の使用部位について、建造物を構成している部材 のうち、適用された部材の種類について分析する。

表 1 の合成樹脂で修復した部材の項目をみると、1978 年の松広寺 枕溪楼の工事では、柱・初重梁・二重梁・ 三重梁・桁・組物・大引 など、多量の部材に合成樹脂で施されたが、それ以降の工事ではほ
とんど柱、初重梁に限定して施したことがわかる。しかし、1992 年 の金山寺弥勒殿の工事以降、柱・初重梁だけでなく、二重梁・桁・ 大斗・大引・隅木・飛檐隅木など施した部材が拡大した。

金山寺弥勒殿以降の工事では、景福宮勤政殿 (2000-2003) と花嚴寺 極楽殿 (2000-2004、図 6-a) は組物にも合成樹脂が用いられた。花巖 寺極楽殿では飛檐垂木にも適用されたが、その後の佛甲寺大雄殿 (2002-2004、図 6-c) や歸信寺大寂光殿 (2003-2005、図 6-d ) でも垂 木に用いられた。このように合成樹脂を用いた部材の修復が多かっ た事例について、該当するところ(太線で囲った箇所)を図示したの が図 6 である。建造物の修理範囲、損傷の状態、部材の年代によっ て修復と再利用の範囲が異なるが、金山寺弥勒殿の工事以降、合成 樹脂を用いた部材の修復が普遍化したことがわかる。

表 2 は、表 1 に示した 46 棟の建造物について、合成樹脂による部 材の修復件数を累積したものである。1978 年から 1991 年までは、 柱系や梁系の部材が中心だったが、1991 年からはより幅広く用いら れることになった。ただし、表 2 で挙げた部材以外は合成樹脂で施 されておらず、限定して適用されているのがわかる。建造物の大小 による差も生じるが、柱系・梁系・隅木系の多くは大径材である。

続いて、部材においてどのような部位が合成樹脂で修復されたの かを分析する。図 7 は松広寺枕溪楼で処置された部材の部位である が、ここでは柱上部や折損した梁仕口など直接的に水平力や垂直力 を支える部位に施されたことがわかる。しかし、松広寺枕溪楼を含 めた試験的施工期以降は、部材の施工部位のうち、直接的な水平力 や垂直力を支える柱上部や組物の仕口部位には施さない傾向がみら れる。

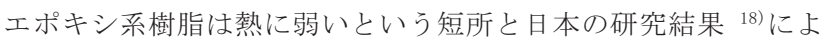
り、現在では直射日光を受ける所は合成樹脂による処置を行ってい ない。また、瓦莫の建物は屋根裏に土が入っているので、荷重を直 接負担する箇所は、合成樹脂だけで処置しないよう注意されている。 荷重を支える部材の部位には使わないか、使用しても金物で補強を している(図 8-c,e)。また水平力や垂直力と関係ない面部位の処理 が増え、従来には施工事例がなかった化粧垂木の化粧面にも施すよ うになった。前述のように佛甲寺大雄殿 (2002-2004) (図 8-a) や歸信 寺大寂光殿 (2003-2005) がその事例であり、伝統的な埋木や知木の代

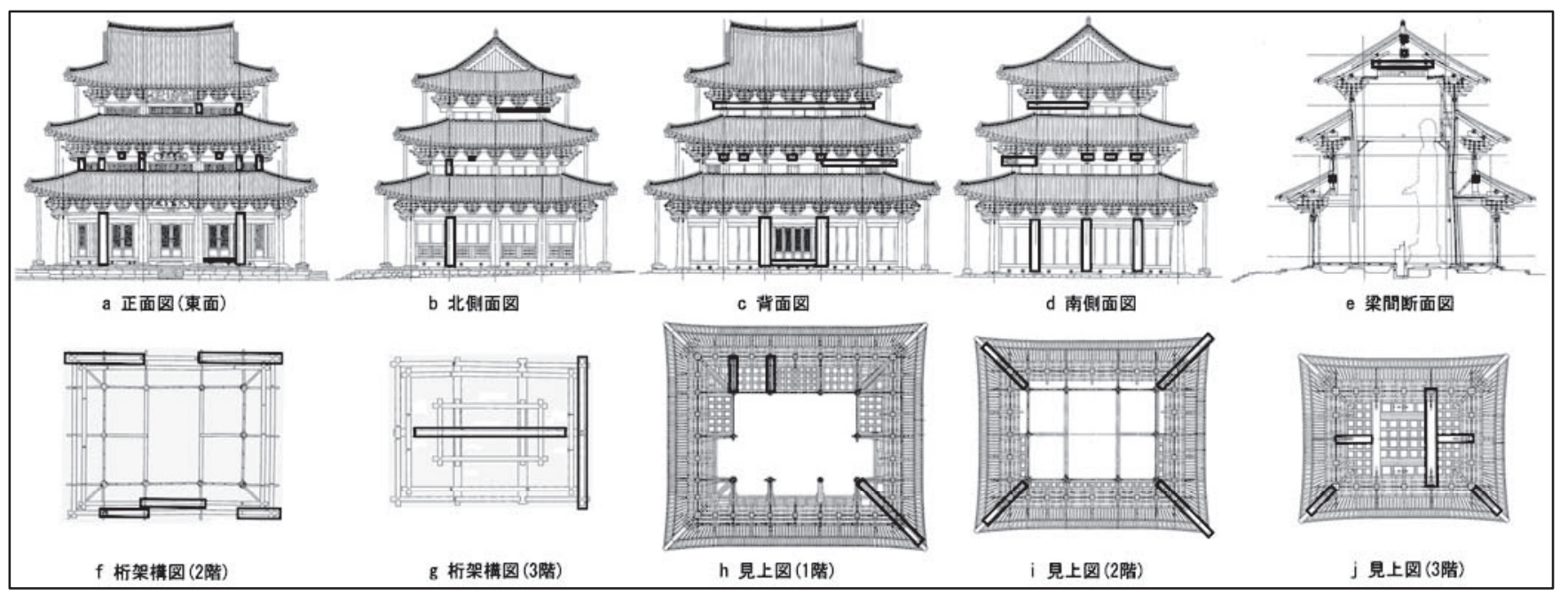

図 5 金山寺弥勒殿の合成樹脂を用いて修復した部材位置 

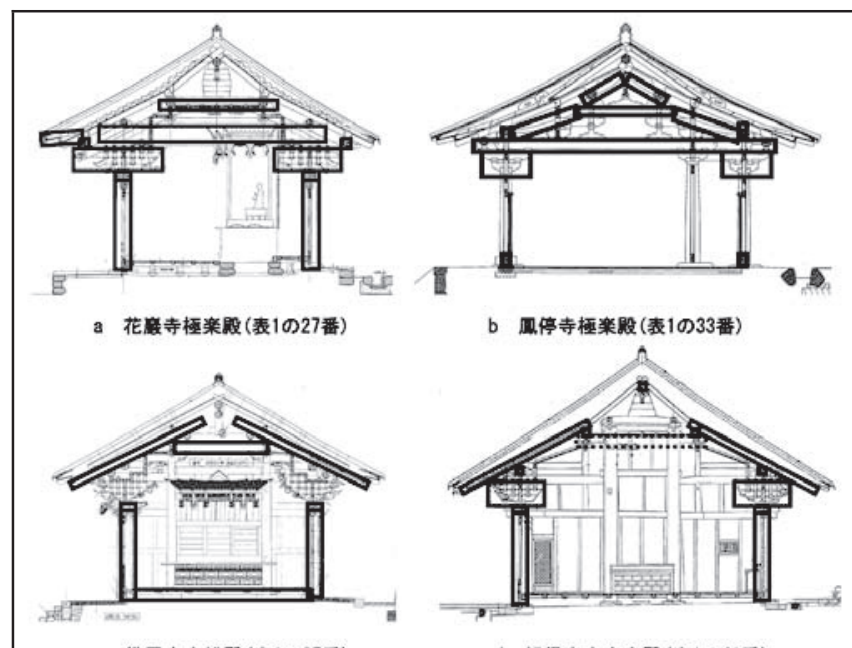

c 佛甲寺大婎殿(表1の35番)

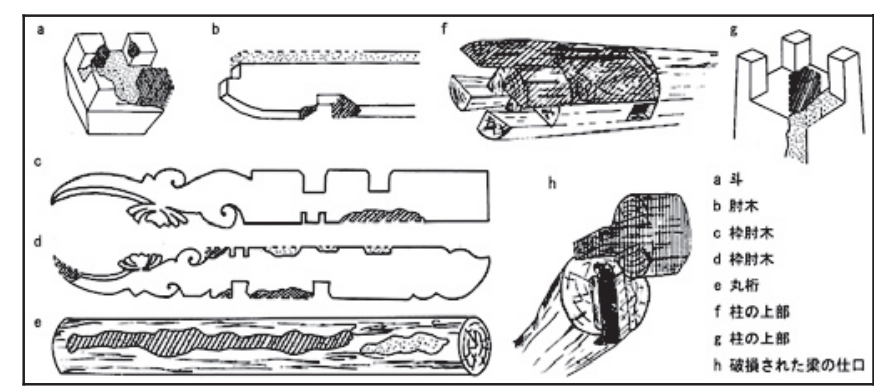

図 7 松広寺枕溪楼の修復部材

枕溪楼、花巌寺極楽殿 (2000-2004)、金山寺弥勒殿 (1991-1999) 鳳停 寺極楽殿 (2001-2003)、 (6)は景福宮勤政殿 (2000-2003)、(7)は江陵客 舎門、景福宮勤政殿 (2000-2003、図 8-f) がその適用例である。た だし、(7)の方法は部材と密着すると考えられ、将来の修理のために は用いないほうが望ましいと判断される。なお、それ以外の方法も これらの経年変化を確認したうえで、耐久性や安定性の面を検討し ていく必要がある。

用としての使用頻度が多くなっていることがわかる(図 8-b, d)。

これまでの結果より、部材は段階的に拡大したが、施工部位は定 型化して限定されている状況がわかる。合成樹脂の施工方法をみて みると、合成樹脂は接着と充填に区別して用いられている。接着は 次の三方法がある。

(1)旧部材と旧部材を接着する。

(2)旧部材と新部材を接着する。

(3)接着部に補強材を加える。

(1)と(2)はそれぞれ単独で施工されることは少ない。(1) は江陵客舎 門 (2000-2004、図 8-g)の大斗、(2)は同じく江陵客舎門や景福宮勤政 殿 (2000-2003)の組物に施された事例があるが。全体的には、(1)や(2) に(3)が併用されているのが実態である。

充填は次の四方法がある。この充填された合成樹脂は整形されて、 いわゆる人工木材と称されるようになる。

(4)旧部材に合成樹脂を充填する。

(5)旧部材に補強材を入れてから合成樹脂を充填する。

(6)旧部材に合成樹脂を充填してから補強する。

(7)継手・仕口の隙間を合成樹脂で充填する。

充填では当然ながら (4)が最も一般的な用法であるが、(5)は松広寺

表 2 合成樹脂で修復した部材の一覧

\begin{tabular}{|c|c|c|c|c|c|}
\hline \multirow[b]{2}{*}{$\begin{array}{l}\text { 番 } \\
\text { 号 }\end{array}$} & \multirow[b]{2}{*}{ 部材 } & \multicolumn{3}{|c|}{ 件数 } & \multirow[b]{2}{*}{$\begin{array}{l}\text { 合 } \\
\text { 計 }\end{array}$} \\
\hline & & $\begin{array}{l}1978-1981 \\
(5 \text { 件の工事) }\end{array}$ & $\begin{array}{l}1981-1991 \\
\text { (18 件の工事) }\end{array}$ & $\begin{array}{l}1991-2007 \\
\text { (23 件の工事) }\end{array}$ & \\
\hline 1 & 柱系 & 3 & 16 & 12 & 31 \\
\hline 2 & 頭貫 &. & 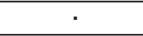 & 8 & 8 \\
\hline 3 & 大斗 & $\cdot$ & . & 2 & 2 \\
\hline 4 & 台輪 & $\cdot$ & $\cdot$ & 3 & 3 \\
\hline 5 & $\begin{array}{l}\text { 組物材 } \\
\end{array}$ & 1 & . & 8 & 9 \\
\hline 6 & 梁系 & 5 & 4 & 17 & 26 \\
\hline 7 & 标 & 1 & $\cdot$ & 6 & 7 \\
\hline 8 & 隅木系 & $\cdot$ & . & 12 & 12 \\
\hline 9 & 垂木系 & $\cdot$ & $\cdot$ & 3 & 3 \\
\hline 10 & 束柱 &. &. & 1 & 1 \\
\hline 11 & 双首竿 & $\cdot$ & . & 1 & 1 \\
\hline 12 & 地貫 & 1 & . & 1 & 2 \\
\hline 13 & 大引 & 1 & $\cdot$ & 2 & 3 \\
\hline 14 & 建具材 & $\cdot$ &. & 2 & 2 \\
\hline & 合計 & 12 & 20 & 78 & 110 \\
\hline
\end{tabular}

\section{4. 合成樹脂の材質的な検討}

合成樹脂には接着剂と含浸強化剤が用いられるが、そのほかに添加 材や補強材もあり、それらを整理したのが表 3 である。ただし、合 成樹脂などの修復材料については、工事報告書等に記載されていない 事例もあったため、現段階で確認できた範囲を整理した。

接着剂で用いられた合成樹脂は、アラルダイトXN1023 (主剂) とア ラルダイト HL1024（硬化剂）、アラルダイト SV427 (主剂) とアラル

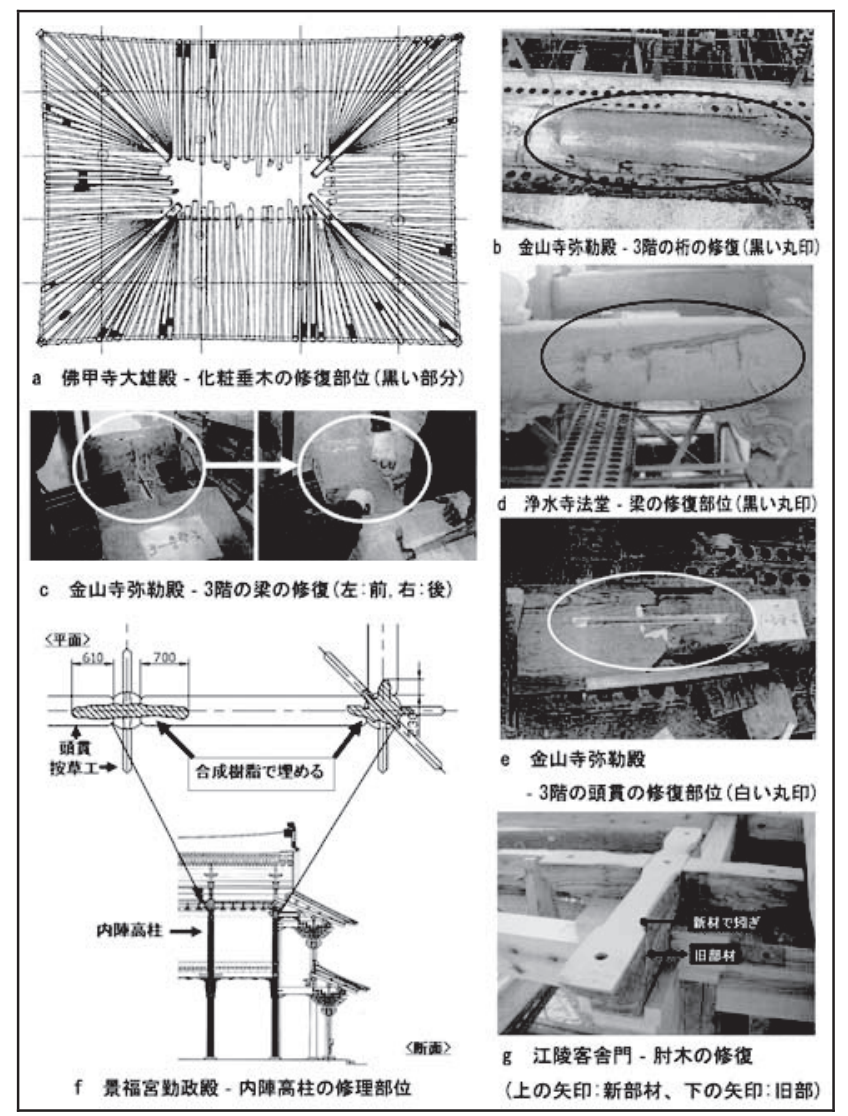

図 8 合成樹脂を用いて修復した部材部位 
ダイト HV427 (硬化剤)、エポンス AR-16 (主剤と硬化剤)の 3 種類に 分けられるが、いずれも、エポキシ系樹脂である。

アラルダイトXN1023 (主剤) とアラルダイト HL1024(硬化剂) は、 1978 年から 1979 年まで、松広寺枕溪楼 (1978-1978)、採薇亭 (1978)、 禅雲寺萬歳楼 (1979)の 3 件で用いられた。このアラルダイト XN1023 は、1976 年から行われた桂離宮の修理工事で主に用いられた合成樹 脂である。赤褐色のアラルダイトSV426 $6^{19)}$ より色が淡くて、松煙を少 し添加することで既存部材と色調を合わせることが容易であり、吸水 性が少ないため耐久性も優れているという理由から用いられた。しか し、施工する場合には、処理室の温度を $20^{\circ} \mathrm{C}$ になよう、すべての 環境条件を作らなければならないという施工の不便さがあった ${ }^{20)}$ 。 そのため温度差に敏感に反応することがなく、より施工しやすいもの に替わることになる。

1981 年以降、アラルダイト SV427 (主剤) とアラルダイト HV427 (硬 化剂) が用いられるようになった。崇陵(東九陵)丁字閣(1981)、花嚴 寺雨花楼 (1981-1982)、金山寺弥勒殿 (1991-1999)、永川鄉校大成殿 (2001)、德壽宮中和殿 (2001)、崇林寺普光殿（2001-2002）、鳳停寺極 楽殿 (2001-2003)、佛甲寺大雄殿 (2002-2004)、歸信寺大寂光殿 (2003-2005)、石南寺霊山殿 (2003-2007)の 10 件が、それで施工され ている。アラルダイト SV427 は木材のみならず、金属材の遺物、土 器および遺構伝写など様々な材料の保存処理に応用される材料で、高 粘性製品である。施工面では、アラルダイトXN1023 ほど温度に敏感 に反応して硬くなることはなく、高粘性で成形加工が容易なことから 汎用されたと思われる。

景福宮勤政殿の修理工事(2000-2003)には、韓国国内生産の合成樹 脂であるエポンス $\mathrm{AR}-16$ が用いられた。エポンス $\mathrm{AR}-16$ は主剤と硬 化剂を $1: 1$ で混ぜて施工する淡黄色の接着剂である。しかし、ここ でエポンス AR-16 が用いられた根拠は判明しない。ただし、アラル ダイト製品と同じエポキシ系樹脂なので基本的に強度面で大きな差 はないが、低粘性なので施工性が良かったとは思われない。

含浸硬化剂には、エポキシ系樹脂とアクリル系樹脂が用いられてい る。エポキシ系はアラルダイトの製品 (8 件)で、アクリル系はリカー ジン ST-001 (3 件)、パラロイド B72 (1 件)である。アラルダイト製品 の変化の要因は明らかではないが、既製品の生産販売システムと関係 があると考えられる。パラロイド B72 を用いた理由は建具の含浸に 有効であったためと思われる ${ }^{21)}$

これにより、接着剂・含浸硬化剂はエポキシ系の合成樹脂が多く、 主にアラルダイト製品が用いられていることがわかる。

添加材としては、おが屑、タルク、グラスファイバー、マイクロバ ルーンが用いられている。タルクは主に化粧品の原料を含め陶磁器の 保存処理などでも添加材として用いられるなど、多様な分野に活用さ れる材料である。マイクロバルンを混合すると、合成樹脂は高強度で 多孔質になり、表面などの加工が容易になる利点がある。

補強材として、当初は鉄棒を用いていたが、木材の水分と結合して 施工後に錆びる欠陥があった。そのため金山寺弥勒殿の工事 (1991-1999) 以降、補強材にステンレス棒が用いられた (図 8-e)。

このように接着剤で用いられたエポキシ系樹脂は、アラルダイト XN1023 からアラルダイト SV427 を用いられるようになったがこれ は施工面での利便性が優先されたことによると思われる。つまり、修
表 3 修復の材料一覧〈使用年次順〉

\begin{tabular}{|c|c|c|c|c|c|}
\hline \multirow{3}{*}{\multicolumn{2}{|c|}{ 区分 }} & \multirow{2}{*}{\multicolumn{2}{|c|}{$\begin{array}{c}\text { 樹脂処理技法の材料 } \\
\text { 製品名 }\end{array}$}} & \multirow{3}{*}{$\begin{array}{l}\text { 使用 } \\
\text { 件数 }\end{array}$} & \multirow{3}{*}{ 年代 } \\
\hline & & & & & \\
\hline & & 主剂 & 硬化剂 & & \\
\hline \multirow{11}{*}{$\begin{array}{l}\text { 合 } \\
\text { 成 } \\
\text { 樹 } \\
\text { 脂 }\end{array}$} & \multirow{3}{*}{ 接着剤 } & アラルダイト XN1023 & アラルダイト HL1024 & 3 & $1978-1979$ \\
\hline & & アラルダイト SV427 & アラルダイト HV427 & 10 & $1981-2003$ \\
\hline & & \multicolumn{2}{|c|}{ エポンス AR-16 } & 1 & $2000-2003$ \\
\hline & \multirow{8}{*}{ 硬化剤 } & \multicolumn{2}{|c|}{ リカージン ST-001 } & $\overline{3}$ & $\begin{array}{l}1978-1979 \\
\end{array}$ \\
\hline & & アラルダイト GY252 & アラルダイト HY2962 & 2 & $1981-1982$ \\
\hline & & アラルダイト DR429 & アラルダイト DH429 & 1 & $1991-1999$ \\
\hline & & アラルダイトAW103 & アラルダイト HY956 & 1 & 1991-1999 \\
\hline & & アラルダイト TR429 & アラルダイト TH420 & 1 & 2001 \\
\hline & & \multicolumn{2}{|c|}{ パラロイドB72 } & 1 & 2001 \\
\hline & & アラルダイトAY12003 & アラルダイト HY956 & 1 & $2001-2003$ \\
\hline & & アラルダイト AY106 & アラルダイトHY956 & 2 & $2003-2007$ \\
\hline \multirow{4}{*}{\multicolumn{2}{|c|}{ 添加材 }} & \multicolumn{2}{|c|}{ おが屑 } & 3 & $1978-2007$ \\
\hline & & \multicolumn{2}{|c|}{ グラスファイバー } & 1 & 1991 \\
\hline & & \multicolumn{2}{|c|}{ タルク } & 1 & 2002 \\
\hline & & \multicolumn{2}{|c|}{ マイクロバルーン } & 1 & 2003 \\
\hline \multirow{2}{*}{\multicolumn{2}{|c|}{ 補強材 }} & \multicolumn{2}{|c|}{$\begin{array}{c}\text { 鉄棒 } \\
z=\end{array}$} & 2 & 1978-1981 \\
\hline & & \multicolumn{2}{|c|}{ ステンレス板 } & 2 & $1991-2003$ \\
\hline
\end{tabular}

理に用いられた合成樹脂は、而久性や汎用性など製品性能の向上に伴 って替ってきたが、施工面での容易性も重視されていることがわかる。 添加剂ではマイクロバルンやグラスファイバー、補強材ではステンレ スやアルミニウムなど、異質の素材が主流となっている。しかし、合 成樹脂の性能向上と安定性を考慮するならば、添加剤や補強材には木 質の素材を再検討する必要があり、代用の材料も考察すべきではない かと思われる。木材に比べると、金属は固まった合成樹脂と分離しや すく、外部からの衝撃があった場合には逆効果が発生し、保存した部 分を破損寸る危険があると思われる。

\section{5. 結}

以上、韓国の木造文化財建造物における合成樹脂を用いた部材の 修復について、歴史的な変遷と展開を検討し、文化財修理を通して 具体例を分析した結果、つぎのように纏めることができる。

韓国の建造物修理には、主として根継、知木、補強金物等の伝統 的な技法があるが、文化財の概念形成や国内外の影響によって合成 樹脂が導入され、試験的な適用から経年変化の確認をへて、1991 年 の金山寺弥勒殿の修理以降に幅広く用いられた。現在は、文化財建 造物の保存修理における技法のひとつとして定着した結果、導入以 前に比べて多くの部材を保存することを可能にしている ${ }^{22)}$ 。

確かに、合成樹脂による部材の修復は、文化財建造物の様々な部 材や部位に適用されてきているが、大径材への適用が圧倒的に多く、 またその用法は伝統的な知木の代替としているのが実態である。荷 重を直接に負担する部位には適用の限界があって、構造材としての 強度確保や科学的な解明が不十分という問題が残っている ${ }^{23)}$ 。

つまり、合成樹脂の材質的特性の向上に鑑みれば、適用部位に合 わせた用法の再検討が必要な時期に来ていると考えられる。またほ とんじが化粧面への適用なので、材質の劣化等の経年変化を検証し、 将来的な合成樹脂の信頼性と安全性を確保することが必要であり、 補強用の素材も検討の余地があると思われる。

\section{参考文献}

1）戶曹、『昌德宮營建都監儀軌』、1833

2）文化財庁、『永川鄉校大成殿修理報告書』、2001

3）文化財庁、『崇林寺普光殿修理報告書』、2002 
4）文化財庁、『昌德宮熙政堂新館-實測修理報告書』、2003

5）文化財庁、『昌德宮亭子實測修理報告書』、2003

6）仁川広域市南区庁、『仁川都護府庁舍捕修工事報告書』、2004

7）文化財庁、『文化財修理標準仕様書』、2005

8）文化財庁、『大漢門修理報告書』、2005

9）大邱廣域市、『桐華寺大雄殿文化財修理報告書』、2007

10）安城市安城市庁、『安城石南寺霊山殿一解體實測修理報告書』、2007

注

注 1）金炳虎「合成樹脂の文化財適用」(『文化財』Vol.13、文化財管理局、 1980)、同「合成樹脂の文化財適用 (3) 一エポキシ樹脂の物理的な性能実験 (『保存科学研究』Vol. 4、文化財研究所、1983)、同「文化財の修理復原」 (『文化財保存科学研修教育教材) 』、文化財研究所、1992)、同「文化財保 存のための合成樹脂の応用」（『文化財修理技術教材（2）』、文化財管理局、 1994）、趙仁淑「桂離宮御殿群の解体修理-全面的な解体修理の記録を中心 に」(『建築歴史研究』Vol. 36、2004) が該当する。金炳虎氏の研究は、合成 樹脂の処置技法の導入前後におけて、当時の新たな修理材料である合成樹 脂の実験・報告である。趙仁淑氏の研究は、桂離宮の工事を通してみた合 成樹脂の処置技法に関するものである。

注 2）趙賢貞・金王稙「合成樹脂を用いた文化財建造物の保存処理事例に関 する研究一日本と韓国の保存処理事例を中心に」『建築歴史研究』Vol. 45 （2006）は、日韓の事例を把握し、文化遺産の保護に関するユネスコ憲章 など国際的な規定を検討したうえで、国際保存理念の観点から合成樹脂に よる部材修復の内容を考察した研究である。本研究は、その既往研究より 韓国国内の研究対象を拡大し、合成樹脂の導入からその後の各事例の施工 部位や技法をより詳しく検討し、演繹的な方法で現段階までの韓国国内の 実態を把握したものである。

注 3）日本では、竹之内裕・川野辺涉「文化財建造物の修復に用いられた合 成樹脂の変遷」（『保存科学』Vol.37、東京国立文化財研究所、1998）が あるものの、韓国では修理事例を包括的に対象とした研究はなかった。

注 4）金王稙「儀軌の建築用語は用語統一の基準になれるのか。」（『建築歴 史研究』Vol.41、2005)。「童發里」、「童發伊」、「東發里」、「同發 耳」は借字であって、意味は同じである。借字は純粋な韓国語(漢字がない 単語の場合)の発音を漢字で書く伝統的な表記法である。

注 5） 根継に関しては、1925 年-1927 年に行われた成仏寺応真殿の修理で確 認できる(杉山信三、『韓国古建築の保存-浮石寺・成仏寺修理工事報告』、 1996、p.19-20)。成仏寺応真殿は、北朝鮮の黄海北道にある朝鮮時代の建 物で、柱 26 本のうち、5 本は新材で取替、15 本は根継・頭継で再利用され ており、近代の修理でも根継の技法は継承されていたことが知られる。な お、当時の修理は日本人修理技術者が関与した。

注 6）ソウル崇礼門(南大門)は、韓国の国家指定文化財の国宝 1 号で、2008 年 2 の火事で一部焼損したが、文化財指定は継続している。現在、その修 復が行われているが、焼損した部材の修復が注目されている。

注 7）ソウル特別市教育委員会『ソウル南大門修理報告書』（1965）p.38。

注 8） 文化財管理局文化財研究所『鳳停寺極楽殿修理工事報告書』(1992)「5. 建物の復元の中で木工事の項目」による。

注 9） 1960 年代は、文化財に関する制度・法律・行政の枠組が整いつつあつ た時期で、文化財保存委員会の設立 (1960)、文化財管理局 (現、文化財庁) の開設 (1961)、文化財保護法の制定 (1962) など、国家主導による文化財保 存政策が推進された。こうしたなか文化財管理局文化財研究室(現、国立文 化財研究所) が設立(1969) され、文化財分野の研究が本格的に進められ、保 存科学は外国の文化財保存を経験した研究者たちにより着手された。当時 の文化財保存科学の動向については、科学技術処『文化財の科学的保存管 理に関する調査研究』(1968)、金裕善「文化財の科学的保存」（『文化財』 Vol.5、文化財管理局、1971)より、知ることができる。

当時の文化財保存の国際的な流れは、UNESCO 開催会議 (1964) で決定さ れた「ベニス憲章-記念建造物及び遺跡の保全と修復のための国際憲章 The Venice Charter(1964)-INTERNATIONAL CHARTER FOR THE CONSERVATION AND RESTORATION OF MONUMENTS AND SITES 」から類推できる。文化財のオーセンティシティ(authenticity)は、 文化財修理における保存技術や技法で保たれ、保存原則は文化財保存科学 の発展をもたらしたと考えられた。韓国においては文化財保存の概念形成 や国内外の影響により、国内の建造物修理に関する技術研究の必要性を認 識することになった。

注 10) 張慶浩氏は「建造物文化財における補修・復元の方向」(『文化財』 Vol.11、1976)において、文化財建造物の保存技術における当面の課題につ いて、第 1 は原形保存、第 2 は破損部の補強・補修・復原、第 3 は現状変
更の妥当性と要約している。

注 11）金炳虎氏は「木造建造物の保存に対する一般的な考察」（『文化財』 Vol.10、1977)において、部材の取替が多いほど文化財としての価值が減少 するので、古材の再用のためには硬化するか、人工木材で補修したほうが 望ましいと述べている。

注 12) 同年には、慶州の雁鴨池で発掘された建築部材の保存処置が行われ た。これは、出土木材であるが、建築部材の科学的な保存処置の初例であ つた。木造建造物の木材と出土された木材ではその物性が異なるため、同 じ建築木材であっても異なる材料や技法で保存処理が施されている(文化 財管理局、『雁鴨池』、1978)。

注 13）金炳虎、前掲注 1) 論文。なお、彼は桂離宮が 1977 年から 6 年間かけ て修復されていた時期に奈良文化財研究所で研修していた。

注 14）キトル(耳機)と言う部材を和訳し、役割が近い部材 が大引である。キトルは柱と柱に置き、床板を支える部 材である（右の図、網掛けした部材）

注 15）按草工は頭貫と直交し、柱頭部から出て台輪や大

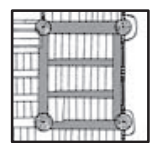
斗、あるいは大斗や桁まで支える部材である。構造材と装飾材の役割を同 時に果たすもので、規模が大きい多包系の建築にみられる。(金王稙、『分 かりやすい韓国建築用語辞典』、ドンニョク、2007、p.128)。

注 16) ソスルハッチャン(ソスル合掌) と

言う部材を和訳し、役割が近い部材が扠 首笔である。ソスル合掌は桁を支え、梁 の上に置く部材である（右の図、網掛け した部材)。

注 17）文化財庁、『金山寺弥勒殿修理報告書』、2000、p.44-45。金山寺弥 勒殿は 1988 年から 1999 年にかけて計 8 段階での修理が行われた。その中 で、木工事は 1991 年から 1999 年まで行われており、本論文では修理期間 を 1991 年から 1999 年とした。

注 18）竹之内裕・川野辺渉、前掲注 3) 論文。

注 19) 日本では施工性が良い SV426 が最近もよく使われている。

注 20）金炳虎、前掲注 1) 論文。

注 21） パラロイド B72 は、粘度がない液体状態なので、塗っても表面吸収 がよく、表面に残存物がない。このような理由で、部材が細く化粧面が目 立つ建具に使われたのではないかと思われる。

注 22）金炳虎氏は、前掲注 1) 論文で「なお、韓国では 30-40\%の取替があっ たが、合成樹脂を使うと $3 \%$ まで取替率を減少させることができると考え られる。なおかつ、工事予算の節減もできると判断される。」と述べている。 ただし、施工部位の限界性などにより、その後の修理では $3 \%$ まで取替率 を減らすことはできていないのが実状である。

注 23) 合成樹脂の強度 (圧縮・曲げ・引つ張り・せん断) については、（樋口 清治「6. 科学的修復技術 - 保存工学-建造物修理と合成樹脂」『新建築学大 系 50-歴史的建造物の保存』、彰国社、1999、p.324-325) が参考になる。た だし、各施工部位の強度実験や経年変化の検討等は本論文の限界があり、 今後の課題である。

\section{図の出典}

図 1）文化財庁、『韓国伝統木造建築物一営造規範調査報告書』（2006）、p.21。 図 2）筆者の現地調査による撮影。

図 3）左の図は、ソウル中区、『崇礼門精密実測調査報告書』（2006）、p.52 と 右の図は、筆者の現地調査による撮影。

図 4）ソウル特別市教育委員会、『ソウル南大門修理報告書』（1965）、p.38。 図 5）文化財庁、『金山寺弥勒殿修理報告書』（2000）、図面編集。

図 6）a は文化財庁『完州花嚴寺極楽殿実測および修理報告書』（2004）、b は文 化財庁『鳳停寺極楽殿修理実測報告書』(2003)、c は文化財庁『佛甲寺大雄 殿修理報告書』(2004)、d は文化財庁『歸信寺大寂光殿修理實測調査報告書』 （2005）より図面を編集した。

図 7）前掲注 1)論文より図面を編集した。

図 8）a は、前掲図 6c、p.338。b, c, e は、前掲図 5、p.301-302。d は江華郡 庁・文化財庁『浄水寺法堂実測修理報告書』(2004、p. 383)。f の上の図は 文化財庁『景福宮勤政殿修理報告書』(2001、p.114)。f の下の図は、申鷹 秀『景福宮勤政殿』（玄岩社、2005、p.375）の図面編集。g は江原郡庁・文 化財庁、『江陵客舎門実測修理報告書』2006、p. 356 の図面を編集した。

(2008年 7 月 10 日原稿受理， 2009年 3 月 12 日採用決定） 